\title{
Entrepreneurial Ability Training of the Economics Management Students Under the Condition of Virtual Simulation
}

\author{
(SUBMITTED BUT NOT PRESENTED)
}

\author{
BAI Lin \\ Economics and Management College \\ Huainan Normal University \\ Huainan 232001, China \\ bailinhn@vip.163.com
}

\author{
YANG Xia \\ Economics and Management College \\ Huainan Normal University \\ Huainan 232001, China \\ xyang8731959@163.com
}

\begin{abstract}
Great importance is attached to the college students' entrepreneurial ability, which has become a promote college talent training quality and education level demands of the Times and de velopment connotation. College students' entrepreneurial ability training ways have been proposed which consist of the teaching concept, methods and means, based on analyzing the entrepreneurial ability components of the economics management students for exploring the suitable cultivating path. Combined with hardware conditions of Huainan Normal University entrepreneurship virtual simulation center, entrepreneurship simulation experiment platform, e-commerce training platform and entrepreneurship supporting platform three platforms have been built, its cultivating ways and results introduced, which included of "1234" teaching practice,

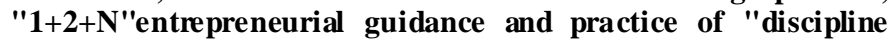
competition" carrier.
\end{abstract}

Keywords-virtual reality; the economics management students; entrepreneurial ability; training way

\section{INTRODUCTION}

"The economy can only guarantee our life today, science and technology can guarantee our tomorrow, but entrepreneurship education can ensure the day after tomorrow" said by the famous economist Cheng Siwei. Premier Li Keqiang on Summer Davos BBS called for "public entrepreneurship, innovation" in September, 2014. Then "develop two engines-public entrepreneurship and innovation, and greater supplies of public goods and services to inspire national entrepreneurship and innovation" have been made in 2015 the government work report. In June 2015, Mr. Yuan Guiren, Minister of Education of the People's Republic of China re-emphasized innovation entrepreneurship education must be brought into the whole process of personnel training, and strengthen the practices from three aspects on expanding the resource sharing, building the practice teaching platform and innovation entrepreneurship competitions. Visibly, developing innovation entrepreneurship education, cultivating high-quality creative and pioneering talents, which is not the only way for university students' ability ascending, but the appeals of time in the development of universities, so does the driving force for the national innovation, social progress and economics growth. College students are the most creative group, also at the age of most creative. Colleges and universities as the main land to incubate innovation entrepreneurship talents, need to solve and think problems such as how to strengthen the consciousness of college students' entrepreneurship and improve their entrepreneurial ability, strengthen the entrepreneurial talent. Firstly, the cultivation of the talents is analyzed. Then, the entrepreneurial ability composition of students in management and economics is studied. Lastly, Huainan Normal University virtual simulation center construction and practice introduced, whose aim is to explore the approaches that suitable for entrepreneurial ability cultivation of the economics management students based on economics and management majors and students' characteristics.

\section{COMPOSITION OF ENTREPRENEURIAL ABILITY FOR ECONOMICS AND MANAGEMENT STUDENTS}

Statistics show that by 2013 June, 2198 universities were approved by the Ministry of education of China, have set up the economy and management specialty. The economics management majors, which as an extremely practical subject relates closely to humanities and social sciences, have wide practicality and operability in business practice. Its students mainly composed of liberal arts students with more active imagination, more discerning eyes at market, stronger entrepreneurial desire and more interests in entrepreneurship compared with students of other disciplines. Therefore, college students majoring in economics management are the new entrepreneurship force, whose capacities and the success rate of entrepreneurship can decide the overall level of student entrepreneurial abilities in our nation to a certain extent. The entrepreneurial skills mainly include the following contents.

\section{A. Professional skills}

Nowadays, the entrepreneurial environments of the market economy demands entrepreneurs to own the knowledge of capturing the business opportunities, marketing, enterprise management, risk control, statistical analysis .etc. Therefore, college students must carefully study expertise and

Sponsor: Anhui Provincial Education Department of China 
methodically grasp professional skills that are practical and operable.

\section{B. Management capacity}

Students entrepreneur majoring in economics and management need to integrate people with various abilities together and optimize the personnel allocation. At the same time, they need to have excellent decision-making skills. Before starting a business, numerous entrepreneurial goals should be analyzed and compared in order to select the best entrepreneurial direction for them to display their special skills and advantages. During the venturing process, finding the essence through complicated phenomenon, analyzing reasons and finding out the real problems are neces sary.

\section{Communication ability}

Since man is the main member of market economics entity and finally makes sense object, any kind of economics activities can't work without people's participation. Consequently, students majoring in economics and management should handle the relationship with the outside world properly, what's more, it is necessary to learn to communicate with all kinds of market economics entities effectively and try to get support of every part if anyone of them wants to start a business success fully. And seek common ground while reserving differences and work together in the direction of the coordinated development concept.

\section{Innovation ability}

It plays a significant role in entrepreneurship. No matter what entrepreneurs adopt new strategy, develop new products, open up a new market or develop business plans, found new enterprises, different levels of innovation activities are all included. Therefore, entrepreneurs should have innovative thinking and capacity for innovation.

\section{COLLEGE STUDENTSENTREPRENEURIAL ABILIT Y TRAINING}

\section{A. The Teaching Idea}

The experience of Chinese successful reform enlightens us: only liberate the productive force and meet the subject requirements, can get effect and success. The key to the development of agriculture is to return the land to farmers, development of industrial development is to return the markets to entrepreneurs, so the successful education reform is to return the classroom to students, taking the students as the center to carry out the education. Adhere to the student-centered teaching concept, respect the students' development needs, has become the college students' entrepreneurial ability cultivation work purpose. With the good development of markets economy and increasingly serious social employ ment situation, more and more college students have are aware of entrepreneurship has been unstoppable trend of the Times, so pioneering awareness gradually strengthened and entrepreneurial intention gradually improved. Facing the requirements of students' entrepreneurial skills upgrading, colleges and universities need to strengthen the teaching reform, perfect rules and regulations, is sue more refined, operational, testable innovative entrepreneurial education programs, constantly increase the funding for the propaganda of entrepreneurship and innovation, strengthen college students' innovative entrepreneurship competition to promote students' entrepreneurship.

\section{B. The Teaching Idea}

John Dewey, American philosopher and educator, as the founder of the pragmatism, thought that "education is life", "college is life" and "learn by doing". At the same time, the colleges should also provide the situation that can cause thought experience, and combine with the practice of activities and projects, deepen the theoretical knowledge. The beginning of thoughts always stem from the difficult situation that is associated with the social life experience, thus a situation that could lead to the experience of thinking need to be offered for entrepreneurial thought and consciousness training and cultivating. How to build situation? How to structure situation? Need to change the way of traditional teaching, promote teachers' entrepreneurship education innovation consciousness and ability ,and enrich teaching forms on the basis of teaching content reform, such as: strengthen the experiment teaching, the proportion of practice teaching with rapid development of network technology, adopt heuristic, discussion-based, participatory teaching and active learning for task-oriented project to be implemented.

\section{The Teaching Methods}

Owning good content and means doesn't enough, specific means of implementation are essential. Just as the English word can't left the context, if the teaching with no practical environment, will out of significance. So if college student innovation and entrepreneurship education is divorced from the real workplace environment, it will finally lack of vitality. Constrained by time, space, opportunity and resource constraints, the college students can't do all kinds of work in the limited four years. But with the development of computer technology, virtual reality technology has provided the possibility of the university innovation and entrepreneurship education practice, which formed in the 1940s, has immersion, interaction, imagination and reality these characteristics, use a virtual system to imitate another virtual simulation of the real system. At present, the technology has developed into the new era of the experimental study, and it has been applied to the urban planning, entertainment, art and teaching widely. Through the construction of virtual simulation experiment center, not only can fully meet the needs of students' autonomous learning, but also can break the limit of time and space. Its flexible and varied means and the integration of all kinds of social and the workplace environment let the students make full use of teaching resources and experience entrepreneurship environment truly. It is available for them to clear their own shortcomings and participate in practical activities to improve their entrepreneurial ability. 
IV. HUAINAN NORMAL UNIVERSITY VIRT UAL SIMULATION OF ENTREREPRENEURIAL ABLITY CULTIVATION PRACTICE

\section{A. Entrepreneurship Virtual Simulation Experiment Center Platform}

Huainan Normal University as an undergraduate course college has more than 50 years' development history. It has focused on building virtual simulation experiment center of entrepreneurship since 2006 based on practical and innovative personnel training practice, aiming to do a good job in college students' entrepreneurial ability cultivation. At present, the center has entrepreneurial simulation experiment platform, ecommerce training platform and entrepreneurship supporting platform these three platforms, covering an area of about 1500 square meters, equipment as sets worth about $\$ 6.3$ million.

Huainan Normal University as an undergraduate course college has more than 50 years' development history. It has focused on building virtual simulation experiment center of entrepreneurship since 2006 based on practical and innovative personnel training practice, aiming to do a good job in college students' entrepreneurial ability cultivation. At present, the center has entrepreneurial simulation experiment platform, ecommerce training platform and entrepreneurship supporting platform these three platforms, covering an area of about 1500 square meters, equipment as sets worth about $\$ 6.3$ million.

1) Entrepreneurial simulation experiment platform: In order to improve the practical ability of students and practical ability of entrepreneurial innovation, the center has introduced three softwares - "Star of Innovation", "the Market ing way", and "Beisen Human Resources Evaluation Software" in 2014, which form the entrepreneurial simulation experiment platform. From each link of measurement of the entrepreneurship, business plan, entrepreneurship preparation to entrepreneurial management to virtual simu lation the whole process of real start-up business, where students as an entrepreneurs feel that they should have knowledge of reserves, professional quality and entrepreneurial ability. Constructing experiment platform of business simulation can improve students' ability of knowledge application and innovative undertaking all kinds of skills, such as opportunity identification, fund raising, business negotiation, encouragement and team management skills. By simulating competition projects, all the students can take part in establishing and managing enterprises. On the other hand, the projects make them realize that it is important to study professional knowledge in the enterprise, society and economics development, which also enhance the interest of entrepreneurial learning and entrepreneurial innovation consciousness.

2) E-commerce training platform: E-commerce as a technical, operational and applied strong professional specialty, it has been a good starting point to the implementation of the "public entrepreneurship, innovation". Therefore, paying attention to its virtual simulation experiment teaching, it is favorable for students to master necessary skills and knowledge of setting up e-commerce project from the perspective of project development; it is also profitable to help students master e-commerce project life cycle and management process, operation mechanism and project management methods; so does help them to master project driven organization with the basic elements from the perspective of function, cost, investment and return. Currently, the institute has electronic commerce specialized laboratory, which accommodates 50 people, what's more, "online shop, searching engine marketing, network marketing, e-commerce security, e-commerce website construction" and so on extremely operated courses have been offered. In 2013, undertaking the training project of Unisplendour Corporation Limited (UNIS), a college period UNIS about "business software development practices in class" in summer was opened. In 2014, undertaking the training with Alibaba Group, using the platform for the construction of local electronic commerce to provide certain space and technical support.

3) Entrepreneurship simulation support platform: To better simulate the entrepreneurial environment, the college set the Yongyu ERP operating system, which teaches entrepreneurship students as a business manager how to reasonably plan enterprise resources according to the changes in the environment from the pers pective of enterprise resource allocation and balance of supply and demand so as to achieve commercial success. At the same time, the Class Warehouse design and analysis system, Tara logistics 3D simulation training system and Anylogic method modeling simulation system have been set. With the technology of virtual reality, multimedia, human-computer interaction, database and network communication, height simulation of the virtual experiment environment and object built as well, entrepreneurship students can quickly understand the logistics process and master skills including production system planning and system design, layout design and optimization design, storage design and planning, supplying chain management and other contents to improve entrepreneurship skills. As shown in Fig. 1.

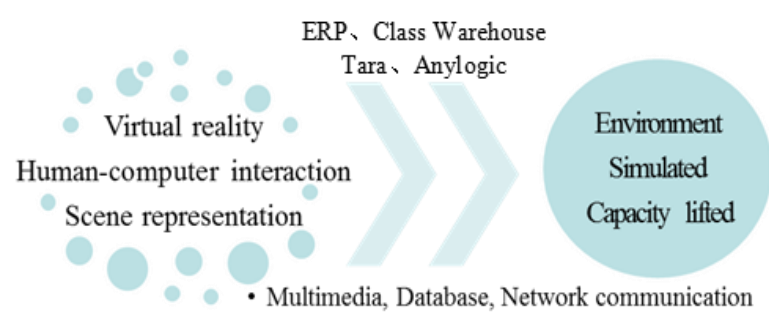

Fig. 1. Approaches to realizing the teaching effect based on virtual simulation

\section{B. Center Measures and Practices}

1) Adhere to the "1234" Practice Teaching: Being a local application oriented undergraduate institution, the college after groping for a long time has established an unique development pattern for the cultivation of students' entrepreneurial ability, 
according to not only the characteristics of the economics and management undergraduate teaching but the characteristics of the students and social de mand changes. Firstly, insist on "one goal" that means starting from the composition of the entrepreneurship ability, scientifically construct entrepreneurship virtual simulation platform and design experimental project, in order to improve the students' professional, management, communication and innovation ability. "2" stands for "the teaching mode owns two lines", namely theory teaching and practice teaching should be parallel. At the same time, a higher proportion of practice teaching should be kept, especially pay attention to practice teaching in the field of virtual simulation platform. Then develop "the trinity", namely the cultivation process should be integrated with omnipotence and special, and melt the teaching and scientific research as a corporation, and the integration of the knowledge impacting and the ability cultivation. Realizing the moderate combination between generalists and specialists based on the integration of multidisciplinary knowledge. "Four abilities" namely to emphasize cultivate students' basic thinking ability, modern general ability, professional ability and entrepreneurship ability. For this purpose, the center has invested by an average of $¥ 500000$ for three-consecutive-year to improve the three major platforms' hardware and software, and adjusted the proportion of practice teaching course to $30 \%$ of the total teaching hours.
2) Implement the Entrepreneurship Guide of " $1+2+N$ ": The college supports the implementation of " $1+2+N$ " entrepreneurship guide mode on the basis of the three platforms for strengthening the cultivation of entrepreneurial talent training effectiveness. The number 1 represents a fulltime staff to be responsible for the entrepreneurship training, entrepreneurship project guiding incubator and academic competitions .etc. While 2 represents for paying close attention to the cultivation of applied talents and the construction of practice base, as well as implement a form of guiding students to start a business with the help of college tutors and mentors outside college. Presently, this college has entered into partnerships with Huainan HaiTong Securities, Mining Institute of Huainan Electronics .etc to build the experiment base outside college and has taken in nearly 20 mentors. $\mathrm{N}$ means absorbing different tutors involving the guidelines according to the different stages of entrepreneurship to help students to develop their entrepreneurial awareness and abilities, college counselors, head teachers, professional teachers and industrial counselor of the college are included. Regularly organize various types of instructor to teach entrepreneurial knowledge based on the platform, and set up the learning organization of network virtual mutual aid for tracking students' entrepreneurship progress, and helping students to solve various problems arising from the entrepreneurship. So far, they have guided more than 30 students online and received good results .

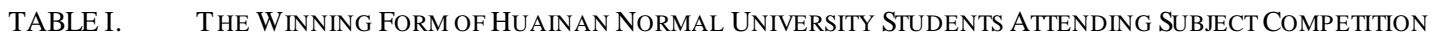

\begin{tabular}{|c|c|c|}
\hline Platform & Name of the competition & Honors and Awards \\
\hline \multirow{5}{*}{$\begin{array}{l}\text { Entrepreneurial } \\
\text { simulation } \\
\text { experiment } \\
\text { platform }\end{array}$} & $\begin{array}{l}\text { The National College Students Extra-curricular Academic } \\
\text { Competition }\end{array}$ & $\begin{array}{l}\text { In } 2013 \text {, at the provincial level won the first prize } 1 \text { item, the second } \\
\text { prize } 2 \text { items }\end{array}$ \\
\hline & $\begin{array}{l}\text { The National College Students "Challenge Cup" Business Plan } \\
\text { Competition }\end{array}$ & $\begin{array}{l}\text { In } 2014 \text {, in the national level won the first prize } 1 \text { item, at the } \\
\text { provincial level won the third prize } 3 \text { items }\end{array}$ \\
\hline & $\begin{array}{l}\text { The National College Students' Career Planning and Students' } \\
\text { entrepreneurship Competition }\end{array}$ & $\begin{array}{l}\text { In } 2013 \text {, at the provincial level won the third prize (employment) } 1 \\
\text { item }\end{array}$ \\
\hline & $\begin{array}{l}\text { The National College Students Xinrui Electronic Retailing } \\
\text { Business Competition }\end{array}$ & In 2014 , at the provincial level won the special award 1 items \\
\hline & The National College Students Marketing Competition & $\begin{array}{l}\text { In } 2013 \text {, at the national level won the first prize } 1 \text { items ; in } 2014 \text {, at } \\
\text { the national level won the second prize } 1 \text { item }\end{array}$ \\
\hline \multirow{5}{*}{$\begin{array}{l}\text { E-commerce } \\
\text { Training } \\
\text { Platform }\end{array}$} & $\begin{array}{l}\text { The National Students Electronics Business "Innovation } \\
\text { Creativity and Entrepreneurship" Challenge Competition }\end{array}$ & $\begin{array}{l}\text { In } 2014 \text {, at the national level won the second prize } 1 \text { item, the third } \\
\text { prize } 2 \text { items, at the provincial level won the third prize } 4 \text { items }\end{array}$ \\
\hline & $\begin{array}{l}\text { The national skills contest financial professional business } \\
\text { competition }\end{array}$ & Won the second prize each one at the national level in 2013,2014 \\
\hline & $\begin{array}{l}\text { The National Skills Contest Mobile Commerce Business } \\
\text { Professional Competition }\end{array}$ & Won the second prize each one at the national level in 2013,2014 \\
\hline & $\begin{array}{l}\text { The National Skills Contest OnlineRetailBusiness Professional } \\
\text { Competition }\end{array}$ & $\begin{array}{l}\text { Won the third prize } 1 \text { item at the national level } \\
\text { in } 2013\end{array}$ \\
\hline & $\begin{array}{l}\text { The Ninth Session of the National Information Technology } \\
\text { Application Level Competition }\end{array}$ & Won the second prize 1 item at a national level in 2014 \\
\hline \multirow{4}{*}{$\begin{array}{l}\text { Entrepreneurs- } \\
\text { hip Simulation } \\
\text { Support } \\
\text { Platform }\end{array}$} & $\begin{array}{l}\text { "AnCai Cup" Financial Investment of Virtual Simulation } \\
\text { Competition }\end{array}$ & $\begin{array}{l}\text { In } 2014 \text {, at the provincial level won the second prize and the third } \\
\text { prize each one }\end{array}$ \\
\hline & The National Skills Competition of International Trade Business & In 2013,2014 at the national level won the first prize each one \\
\hline & The National Students Sand T able Simulation Competition & $\begin{array}{l}\text { In } 2013 \text {, at the provincial level won the second prize } 1 \mathrm{item} ; \operatorname{In} 2014 \text {, } \\
\text { at the provincial level won the first prize } 1 \text { item }\end{array}$ \\
\hline & Chinese College Students Computer Design Competition & $\begin{array}{l}\text { In } 2013 \text {, at the national level won the third prize } 1 \text { items; in } 2014 \text {, at } \\
\text { the national level won the third prize } 2 \text { items }\end{array}$ \\
\hline
\end{tabular}


3) Cling to "Discipline Competition" Entrepreneurial Carrier: As an important form of practice teaching, subject contest can improve students' innovative ability significantly, which is good for trained inter-d isciplinary comprehensive and innovative talents. Since its establishment, the college has strengthened the training of the practical skills of students by subject contest. Through setting up the experts, students and the works database, to bring outstanding students who own entrepreneurial passion and entrepreneurial ideas into the students system as well as to take projects which are innovative and creative and suitable for business into the works system, called "three databases" that interact positively. Besides, through achievement exhibition of subject contest, entrepreneurship forum, interviews and reports .etc various forms to foster the outstanding entrepreneurial projects, make further efforts to publicise start-ups stories and incubate the results of entrepreneurship, lead more students to improve entrepreneurial ideas and enhance their entrepreneurial capacity through participating in the practice and perfect platform of discipline competitions. Meanwhile, rely on excellent software and hardware conditions, the college actively supports and organizes regularly the economics management students to participate in competitions at all levels of subject, to deepen the theoretical knowledge, cultivate students' innovative spirits and pioneering consciousness, professional skills. Last three years, more than 20 field events have been undertaken, 3000 people has involved every year, and the award-winning works more than 120 pieces, award-winning events involved business, finance, international trade, accounting, electronic commerce, computer design class and so on, which has provided a powerful ground and technical support for student academic skills competition and innovation development training program. In 2014, there were 30 team project works which gain the provincial level honor. National awards have been gotten in the national skills Competition of international trade business and provincial awards in the National student sand table simulation competition for five consecutive years. Especially, in 2014 the college obtained the honor of Anhui Province organization award for outstanding colleges and universities in the national students electronics business "Innovation Creativity and Entrepreneurship" Challenge Competition. Awards are shown in table 1.

\section{CONCLUSIONS}

Huainan Normal University through constructing simu lation experiment p latform, e-commerce training platform and business simulation support platform to provide students with high simulation of real work environment, which emphasizes some points as follows in the as pect of training the students' entrepreneurship ability:

1) Pay attention to the infiltration of teaching reform: In the process of teaching reform, it has changed from the original pure theory class teaching to both theoretical and experimental courses. 56 experimental courses which cover International economy and trade, marketing, e-commerce, accounting, financial management and so on undergraduate majors have been offered based on the 11 laboratories. Besides, it was responsible for student internships of college and the transformation from outside disperse investigation into the campus simulation training and outside training combining practice. By creating diverse experimental training environment, improving the practical ability of students, stimulating students' entrepreneurship awareness further and strengthening students' professional skills after 56 semesters undergraduate internship.

2) Pay attention to highlight the professional characteristic: Since it was founded in 2006, professional construction and reform has been strengthened. Combined with the demand of the market economy to set up professional and increase support to e-commerce and international trade major. Multi-level student competition activities ought to be held for constantly enriching the connotation of the various professional construction, unceasingly highlighting professional characteristics. By conducting more than 360 experimental items with the combination of basic type, comprehensive application, the actual operation and design of innovative, cultivating students' practice ability and innovation spirit, improving students' thinking ability and enhancing students entrepreneurial skills.

3) Pay attention to exhibiting the characteristics of the professional characteristics: The innovation activities of students vigorously have got supported relying on practice platform, simulation experimental platform, the database resource platform, the internet and campus network information platform and practice base platform those 5 major functional platforms. In 2013, the college purchased Beisen Human Resources Evaluation Software, focused on the career planning of students, enterprise consciousness guidance and various evaluation methods that should be mastered by students, helped them to improve their practical operating abilities of business management. In 2014, on the foundation of the marketing software and the venture star professional business simulation software, students' entrepreneurial thinking has been training, the process of supplying chain enterprises got understood, whose aim were to help students learn scientific management decision-making and reduce business risks.

In a word, the construction of virtual simulation experiment center has provided a range of powerful platforms, which are helpful for expanding the students' thinking and improving their overall understanding of entrepreneurship, making up the defect of insufficient practical ability. For students not can help them to enhance the ability on identifying enterprise needs and business opportunities, and reducing and avoiding the enterprise risks, but can promote innovative thinking, teamwork and interpersonal communication ability. The platform construction has achieved some effects, the college will take "resource sharing, plan science, focus on outstanding" 
as the target, continue to strengthen the construction of entrepreneurship virtual simulation experiment center, for promoting teaching reform and teaching resource application and sharing.

\section{ACKNOWLEDGMENT}

The work was supported by Base key project of Anhui Provincial Education Department in 2013 "Study on the independent innovation ability of the resource-based city" (No.SK2013A177) and Masters studio to develop and expand the core socialist values of Anhui Province higher education revitalization plan of China (No. 2014FDYMSGZS001-07).

\section{REFERENCES}

[1] The Ministry of Education of the People's Republic of China, The Ministry of education of higher college list, the newly approved college list.http://www.moe.gov.cn/publicfiles/business/htmlfiles/moe/moe_229/ 201306/153565,2013.

[2] Qiong Li, The Elements and the entrepreneurial capacity of business in higher education training, Forum on Contemporary Education, vol. 21,2011,pp.14-17.

[3] Cheng Sining, Geng Qiang, Jiang Wenbo, Zhan Yongning, Application and practice of virtual simulation technology in experimental teaching of electrical courses, Experimental Technology and Management,vol.7, 2013, pp.94-97.

[4] Chu Hanfang, Zhu Yankong. Practice and exploration of entrepreneudal virtual simulation experimental teaching center, Experimental Technology and Management, vol.12,2014,pp.97-100.

[5] Ivey,A.A, and Robin,S.S, "Role theory, role conflict and counseling", Journal of Counseling Psychology, vol.13, 1963, pp.29-36.

[6] Bentley, J.C, "Role theory in counseling: A problem in definition," Personnel and Guidance Journal, vol.45, 1965, pp.11-17.

[7] Trow Martin, Problems in the transition from elite to mass higher education, Paris: OECD, 1973, pp.51-104.

[8] Haettenschwiller, D.L, "Control of the college counselor role," Journal of Counseling Psychology, vol.17, 1970, pp.437-442.

[9] Xiaohong Wu, Min Wang, Tiangang Qiang, " $1+1+n$ tutorial" entrepreneurial talent training mode construction-Taking northeast forestry university traffic instit ute for example, Hei Longjiang Researches on Higher Education, vol.7, 2013, pp.151-153.

[10]LIPing, MAO Chang-fie, XU Jin, Construction of the national virtual simulation experiment teaching centers, Improving the experimental teaching information in higher education, Research and Exploration in Laboratory, vol.11,2013,pp.5-8.

[11]Huang Shunrong, Shi Zhiyuan, Summing up earnestly for reality checks construction in experimental teaching center of virtual simulation in colleges and universities of Fujian Province, Experimental Technology and Management, vol.10,2014,pp.13-16. 